\title{
1. Introduction: architecture and modern cities
}

The city is an oeuvre, closer to a work of art than to a simple material product. (Henri Lefebvre, 1996, p. 101)

Cities are built environments and as such they have always been the sites of imaginative and purposeful architectural structures and spaces. Usually they have been constructed to privilege some specific political, ceremonial or religious movement, or to serve some public function, such as a market, or theater, or administrative complex. The great urban centers of Asia, the Middle East and the Mediterranean have long been cherished for the beauty and the architectural imagination and innovation they have exhibited. They are properly seen as evidence of the imagination and intelligence of their designers and builders. Angkor Wat, the Forum, the Acropolis and Chichen Itza are widely celebrated and are the destination of hundreds of thousands of curious tourists and of archeologists and scholars every year. Built with a religious or political objective in mind these and many other similar sites were tied to a region and sought to serve that region in a specific way. When the center was the center of an empire the center was dominant, until its ultimate collapse or abandonment, and other regional centers of the empire were subordinate.

Societies and their cities have evolved dramatically in recent centuries so that the ceremonial and religious aspects of our built environments, while still present, have been eclipsed by other more pedestrian aspects. Perhaps this is because what we value most highly, if not worship, is now more mundane and "practical." Hence, while we still build large religious buildings, rarely are they great or awe-inspiring. Our most distinguished architects now devote their skills to towers of commerce, to indicators of city aspiration, to institutions of cultural display and performance, and to status enhancement, among others. The world economy and society are too extensive and variegated for there to be one imperial center; in its stead we have scores of politically delimited national spaces, each of which has its own values and objectives. This has given us a world not of a dominant imperial center but of many actors each of which is seeking to ensure its own economic survival and competitiveness. To a significant degree 
architecture has become a tool in this struggle among national economic entities.

Conversely, public spaces are the absence of buildings other than statues, boathouses and so forth. Often the spaces are created around buildings, as in the Le Corbusier Radiant City plan, while at other times buildings are placed around the space, as in Central Park in Manhattan. While some parks, such as Hyde Park in London, are surrounded by low level buildings, and are designed to bring something of the countryside and nature into the city for the pleasure of residents, Central Park reminds one of a space that was created by stacking living units on top of one another in apartment towers. In both instances the park is a public space that is designed for repose, recreation, strolling, and admiration of natural beauty. Even small towns have parks, from the New England town commons to waterfront beautification schemes and playing fields of cities and towns of all sizes and importance.

Not all significant architectural works are situated in cities, large and small; many works such as walls, dams and temples are located in rural areas. But in this book we focus specifically on the relationship between the architectural feature and the city in which it is situated. These featured works have a role to play in the life of the city and a function in the city's economic attractiveness. This interplay between city and architecture will be the subject of this book: indeed the use that city leaders make and have made of architecture. We will find that significant architectural features are a sine qua non of the successful city, not just their presence but specifically what they can do to enhance the city and its competitiveness. Again, in the words of Le Corbusier, "Civic pride becomes incarnate in the material achievements of architecture" (Le Corbusier, [1929] 1987, p. 242).

\section{THE MODERN CITY}

Since the mid-19th century, cities have developed into the principal agents in the global economy. National and sub-national governments are invariably torn between the competing interests and demands of city and rural interests. Cities are also relatively liberal or left-wing in their politics, and this is often in conflict with conservative administrations at the higher levels of government, with the latter being reluctant to transfer funds to the former. The enhanced role of cities is in part the consequence of changes in technology that dramatically altered both the environment in which they existed and their capacity to act in new and more global activities. City leaders have consciously and purposefully undertaken initiatives to advance the competitiveness of their city in relation to others with which 
they are in competition for plant locations, jobs, production, exports from the region, and recognition on the part of individuals and firms in other cities. City leaders have utilized a wide variety of measures to achieve these objectives, from public relations efforts to investment in infrastructure to currying favor with higher levels of government for advantages in taxation and regulation. They have designed metro-wide strategic-economic planning initiatives that have aimed at enhancing the city or in redefining its place in the global economy. In the words of Charles Landry, "For those not in the world league or key secondary cities like Singapore or Sydney, there is intense competition to show distinctiveness. Beyond the cultural and business facilities expected of every large city, the task is to show difference" (Landry, 2000, p. 145).

It was always thought that the economic game was played by larger cities, and the larger the better. Saskia Sassen wrote of New York, Tokyo and London being global cities, cities that were at the pinnacle of decisionmaking and command in the global economy (Sassen, 1991). Others wrote of world cities and of global urban regions (Taylor, Peter J., 2004; Scott, 2012). Size brought economies of agglomeration, including global hub airports, the full array of financial and professional services, major research universities and an ambience that was attractive to a younger, high technology labor force. All other cities accepted more humble roles, as was appropriate for their lower position in the global urban hierarchy. Large cities seemed to have it all - dynamic decision-making and economic power in the city center, leafy suburbs for upper income executives with families, more modest housing in the city itself for lower income workers, and ample space on the edge of the city for corporate campuses when the city center was no longer the ideal company site. In recent years, however, the diseconomies of size have begun to emerge - congestion, pollution, lack of public security, impersonality, higher taxes and so forth. Many of the most recent mega-cities, such as the many that have emerged in China, and cities such as Mumbai, Cairo, Jakarta, Delhi and Lagos, are fraught with these problems and with others such as slums, and large populations in extreme poverty.

This brought forth new life for smaller cities. Allen Scott observed that

there are numerous small cities in the United States where abundant stocks of cognitive-cultural human capital can be found. These are represented by college towns like Gainesville, Florida; artists' colonies like Taos, New Mexico; tourist centers like Savannah, Georgia; small but dynamic foci of high technology production like Austin, Texas; and so on. (Scott, 2012, p. 90)

In the individual chapters that follow, we will comment on the competitiveness-related architectural work that has been done in smaller 
cities such as Columbus (Indiana), St. Louis, Santa Fe, Lund, Aalborg and Cambridge.

From the first years of the 20th century, writers have analyzed and commented on the essential attributes of urban society. This was at the height of industrialism, with its demands for concentration of economic activity, for suitable labor, for private investment in plant and equipment and public investment in transportation and other infrastructure, and for favorable government regulation and taxation. As we examine the individual aspects in the chapters that follow we will have recourse to the writings of many seminal writers, including Camillo Sitte, Jane Jacobs, Richard Florida, Louis Wirth, Charles Landry, Allen Scott and Ed Glaeser among others, as well as major architects and planners such as Frank Lloyd Wright, Le Corbusier, Mies van der Rohe, Eliel Saarinen and Witold Rybczynski.

Historically, cities had been situated with regard to modes of transportation. At first this meant harbors, large rivers - hopefully with access to the sea - or large inland lakes. One thinks naturally of Athens, Rome, London, Barcelona, Genoa, Geneva, Paris, Stockholm and Copenhagen in Europe, and the large cities of the Atlantic, Pacific and Gulf shores, the cities of the Great Lakes and St. Louis in the US, and Montreal, Toronto, Halifax and Vancouver in Canada. But beginning with the 19th century other locational factors gave rise to cities such as Denver, Dallas, Atlanta, Milan, Berlin and Calgary. For many it was a new mode of transportation, the railway, trucking and finally air that were important locational factors. All of these cities, and many others, sought to attract production facilities, labor, residents, tourists, financial institutions and other factors that would enhance their economic vitality and competitiveness. One of the most potent tools these cities had at hand was the construction of architectural works that would facilitate their acceptance by other cities as places of significance, as places that must be respected and taken seriously. Unlike Charlie of StarKist tuna fame, there was no confusion between "tasting good" and "good taste" - these cities wanted structures of good taste that would be highly regarded throughout the world.

Industrialization brought with it the great technological advances in materials and structure that have made it possible to realize the architectural works individuals have imagined. It also brought with it increased population density and the need for specialized structures such as housing for workers, office towers, integrated factories, highways, bridges and airports, as well as suburbs, shopping centers, parking facilities and large university campuses. At first it became possible for production units to be concentrated into large integrated facilities such as Ford's River Rouge plant and huge aircraft, steel and chemical factories and districts of the same industry. After World War II, technology advanced in ways that 
made it possible to break up the large production units and to situate each individual activity in a location that was optimal for it, albeit not for the entire operation. Geddes referred to this, in 1915, as the shift from "paleotechnic" (18th- and 19th-century industrialization) to "neotechnic" (or modern) industry, although he romanticized it a bit by suggesting this was an evolution from "individual money gains, to the maintenance and evolution of life" (Geddes, [1915] 1968, Ch. IV). Each of these two conceptualizations of industrial activity called forth distinctive architectural projects and also called into question what had suited the previous system: hence the rise and fall of industrial districts and even cities, so dramatically evidenced by the US Industrial Heartland becoming the Rust Belt, and similar experiences in industrial locations throughout Europe and other industrialized countries.

Accompanying this change in economic fundamentals was a change in what we would consider to be the fundamental determinants of urban competitiveness. During the industrialization period cities were more or less competitive in accordance with their endowment of "hard determinants," that is industrial plant and equipment, access to transportation, port and rail facilities, labor with the needed skills, sufficient adequate housing, and access to raw materials. The reader can consider large industrial cities of the 19th century for confirmation of this. Great industrial centers were created around steel, aluminum, transportation equipment (including aircraft in the 20th century), textile and clothing, and processing of timber, grains and other materials. The endowment of hard assets would correlate closely with the ranking of cities according to competitiveness, although these studies were not conducted until fairly recently.

In the more recent period, heavy industry has given way to financial and professional services, technology-based manufacturing, aerospace, biopharmaceutical and medical technology, and research-based activities. The "hard" determinants were no longer of a dominant importance for a city's competitiveness; they were replaced by "soft determinants." These determinants include aspects that are of importance for the highly demanded and mobile workers in higher technology knowledge-based employment, and include public security, health care, accessible recreation, cultural facilities, high quality education from pre-K through to graduate programs and research universities, and good transportation. Hence, when the city of today seeks to enhance its economic vitality and its competitiveness, it is these latter assets it wants to enhance, and this has powerful impacts on the sorts of architectural projects it seeks to realize. It must be noted that some of the most competitive cities are small in population but endowed with one or more universities or colleges and a medical complex. 
We will explore the sorts of projects cities have sought during the 20th and 21 st centuries as we go through the chapters of this book.

\section{HOW DOES ARCHITECTURE RELATE TO THIS?}

In Frank Lloyd Wright: In the Realm of Ideas, Frank Lloyd Wright is quoted as having written: "Architecture is that great living creative spirit which from generation to generation, from age to age, proceeds, persists, creates, according to the nature of man, and his circumstances as they change. That is really architecture" (Pfeiffer and Nordland, 1988, p.7). Karsten Harries continued: "'Architecture' names, first of all, the art of building and, second, any structure raised in accordance with the rules of that art" (Harries, 2008, p. 19).

To put it more mundanely, the substance of architecture can be thought of as: 1) any human-made building or structure, 2) a design for a city, town, park or landscape, 3 ) the art or science of designing and building buildings, structures, objects and outdoor spaces, and 4) a plan for organizing space. From "age to age" and from place to place different things are demanded, as will be shown in the description of book chapters that follows this section. Wright's "living creative spirit" is the guiding force behind all of these aspects of architecture. Charles Landry linked this to the project of this book when he wrote: "Creativity has risen because people have realized that the sources of competitiveness now happen on a different plane and they need to learn afresh how to compete beyond merely low cost and high productivity" (Landry, 2006, pp. 391-392). Patrick Geddes put it this way: "we must ... seek to enter into the spirit of our city, its historic essence and continuous life" (Geddes, [1915] 1968, p. xxvi). Each time and place imposes its own individual demands.

We will not examine the theory or history of architecture, in this book, nor will we focus on techniques of building and construction. We will not be concerned specifically with "great architecture" or with prizewinning buildings; rather our focus will be on the ways in which, over time, architecture has been used to define and redefine a city, both visually and functionally, and to enhance its competitiveness. Great buildings and other architectural features symbolize the essence of a city, hopefully more truthfully than just the essence that city leaders want to project for it. These architectural projects have impacts, both positive and negative, on the individuals who work and live in them. A city's architecture can attract firms, skilled workers, tourists and entrepreneurs - or it can repel them. This results in architecture being an element in the economic-strategic plan of a city administration. It has been said, perhaps apocryphally, 
that, in Richard M. Daley's Chicago, the plan for a building would have to be reviewed by the zoning board, a building commissioner, the planning agency and so forth. After all of this, the blueprint would be put on the desk of the mayor and after a while he would declare that "this is a Chicago building" or it "is not." The mayor's overall conceptualization of the city, the aspirations of its residents and how the proposed building contributed to them was all that mattered, for better or worse.

There are many uses we may make of architecture, some of them inspirational, others merely functional, and some responding to rather base motives. The question we must raise here is: What have architects and writers about urban space written that is of benefit to city residents as they try to realize the aspirations they have for their city and for their lives? How have they facilitated achievement of the objectives of city leaders and planners as articulated in the previous section?

We will focus on four ways in which architects have spoken to the issues that confront city economies in the contemporary world. First, the factors that make a city attractive in the modern economy of today differ greatly from those that were important a century ago. Second, there has developed a powerful need for a city to distinguish or differentiate itself among a world of competitors for plant locations, factors of production and so forth. Third, the importance of city size has been significantly altered in recent decades, with smaller cities gaining in viability. Fourth, technological change has continued unabated and continues to impose its imperatives and possibilities on all aspects of city economic life.

The modern economy has evolved from manufacturing activity done in fixed locations that are endowed with certain hard assets to one of relatively mobile service and technology-dominated activities that give priority to soft determinants. To attract the skilled and mobile workforce, cities need to provide congenial places in which these workers can lead the lives they seek, for themselves and for their families. Both Le Corbusier and Frank Lloyd Wright offered visions of urban space that were largely rejected by the individuals who had to live and work in these spaces. Le Corbusier sought to create higher density cities of tall buildings separated by green areas, like the apartment areas one sees in Moscow. Creative use of the automobile would make for city centers that were less congested than were the cities that the 20th century inherited (Le Corbusier, [1929] 1987, p. 170). When these principles were applied to Rotterdam they were, as we shall see in Chapter 10, rejected by the city residents; when they were imposed on residents who had less control over their lives, principally in the low income housing blocks of major US cities, they were soon dominated by a variety of social pathologies and, as with Pruitt-Igo in St. Louis and the Robert Taylor Homes in Chicago, were demolished. 
Wright, too, was taken with the automobile and modern telecommunication and argued that the traditional city was soon to die. His Broadacre City model was composed of one-acre plots of land with room for a house and a garden, connected to the rest of the world by an extensive network of roads, and a space of habitation that could go on endlessly. There was no real city center, but shopping centers were linked by roads and by what decades later became the interstate highway system. Rybczynski sees this as Los Angeles, where Wright lived for a while, writ large (Rybczynski, 2010, p. 70). Of course, cities did anything but disappear, and Wright ultimately designed his famous mile high skyscraper for government services in Chicago. Of course, Joel Garreau's Edge City with its corporate campuses and large-lot residential areas is, to a certain degree, a representation of what Wright foresaw (Garreau, 1991, Ch. 1).

Quite the opposite of these two architects was the most famous critic of architects and their plans - Jane Jacobs. Jacobs, who defeated Robert Moses in his effort to destroy much of Lower Manhattan with a multi-lane east-west expressway, was famously tied to her Hudson Street neighborhood in Greenwich Village in Manhattan. She was dismissive of virtually everything from urban planning professionals, stating that: "From beginning to end, from Howard (and the Garden City movement) and Burnham (principally his City Beautiful movement) to the latest amendment on urban-renewal law, the entire concoction is irrelevant to the workings of cities. Unstudied, unrespected, cities have served as sacrificial victims" (Jacobs, Jane, [1961] 1992, p. 25). By ignoring how people actually live and interact, planners and architects such as Le Corbusier, in her opinion, "assumed the statistical reordering of a system of disorganized complexity, solvable mathematically; his towers in the parks were a celebration, in art, of the potency of statistics and the triumph of the mathematical average" (Jacobs, Jane, [1961] 1992, p. 436). She, on the other hand, celebrated the lack of an imposed order and the joy and spontaneity of the human beings who actually inhabited the city, and functioned in the often spontaneous modern economy.

The evolution of cities in the global structure has made it necessary for each city to distinguish or differentiate itself in the global context, if only to gain some competitive advantage or stature. A century ago, Geddes wrote of the need to realize the "character and spirit" of an individual city in the emerging "neotechnic" economy (Geddes, [1915] 1968, Ch. 17). Today it is less the nature of the city that planners want to celebrate, but rather some distinctive feature that will contribute to the attractiveness of the city to economic actors, whether firms or workers, all of which are highly mobile.

One of the most obvious initiatives has been the desire to construct what must at the time be "the world's tallest building." In some places the 
tallest building has been warranted by economic factors such as the price of land, as was the case with 19th-century Chicago, with its city center confined by Lake Michigan to the east and the Chicago River to the west. "Building up" was a rational solution to a real problem. Given its geology and the fact that it is an island that is quite limited in its extent, New York was characterized by a series of ever taller buildings that were identified with major US companies, including the New York World Building (1890), the Manhattan Life Insurance Building (1894), the Singer Building (1908), the Metropolitan Life Insurance Company Tower (1909), the Woolworth Building (1913), the Bank of Manhattan Trust Building (1930) and the Chrysler Building (1930), each of which claimed title to being the tallest building in the world at the time. Together, over four decades, they helped to establish New York as one of the principal, if not the principal, cities of business in the world.

The combining of corporation headquarters and major financial institutions has been a formula for all cities seeking to distinguish themselves through a strategy of seeking to assert their status as centers of economic clout. A city that is based on high level services rather than manufacturing seems to be a natural place for architects to be hired to design buildings that will give substance to the city's claim for elevated status or differentiation from other cities that are otherwise often very similar. As we will show later, the Petronas Towers did this for Kuala Lumpur, as did the Burj Khalifa for Dubai. Neither of these cities was seen as a principal economic center until these structures brought them to the world's attention. We will discuss this in the context of the concept of "city branding," in Chapter 6.

In the previous section we quoted Scott on the importance of city size and on the attractiveness of smaller cities, cities other than the global and world and mega-cities that have captured so much attention. Here we will discuss the relation between the spatial or physical size of a city and the work of architects and the practice of architecture. Some have argued that cities should be very low density places lacking a strong center and with residences and places of work and production spread out over a great space. This was the approach of Frank Lloyd Wright in his Broadacre City with its Usonian home and its Architecture of Democracy (Wright, 1945). The use of the automobile and of telecommunications made this conception of a city conceivable, and was, for Wright, a way of maintaining democracy, a relatively egalitarian distribution of income, in the political structure of social democracy. Corbusier used the automobile and telecommunications to realize an alternative end, that of a large number of very tall buildings separated spatially by extensive green areas - in his plan the buildings would be placed on 15 percent of the land and the rest would be planted (Le Corbusier, [1929] 1987, p. 102). Beyond them lower 
structures would extend out to the fields where food was grown. Both of these schemes would generate what is now derogatorily referred to as "sprawl." Sprawl is alternatively seen as a situation in which individuals can all realize a Wrightian home and garden on one acre of land, among other things, or conversely as the leapfrogging of empty spaces to build on cheaper land farther from the city center, which generates enormous diseconomies and waste in terms of time to do anything other than swim in one's own pool and of energy used in transportation and in inefficient single dwellings.

At the other end we have the extensive groupings of high rise apartment and office buildings that dominate places such as Manhattan where land is physically limited and there is no alternative to building up, or the many places in China where clusters of tall residential buildings are situated seemingly with more regard for the availability of zoning permits and financing than for the availability of potential residents, or the cities that seek to call attention to themselves, the subject of subsequent chapters of this book. Many of these tall structures are quite magnificent and contribute much to avoiding the creation of sprawl. It is in these denser aggregations that one finds the great cultural institutions, such as museums, concert halls, theaters, and the creativity that occurs in environments that offer opportunities for the much vaunted face-to-face contact and transfer of tacit knowledge. Architects have responded marvelously to the need for buildings to house these cultural activities in virtually every city of consequence.

Technological change has enabled great architects to imagine and then to construct the buildings that have contributed so much to the attractiveness and vitality of our cities. Buildings went from Burnham \& Root's Monadnock in Chicago, in 1891, with its 12-foot thick at the base walls (needed to support the weight of the ten stories of masonry walls), to their steel skeleton frame glass Reliance Building and Jenney's Home Insurance Building (the first skyscraper) four years later, to the Burj Khalifa, in Dubai, with 183 floors and a height of 2722 feet. Projected for completion in 2020 is the Kingdom Tower in Jeddah with a height of over 3300 feet and 252 usable floors. All this happened in just 130 years, thanks to the ingenuity of the variety of professionals involved in this development. Steel framing was the first major innovation, as it allowed for the extreme height of buildings that was not possible with stone, brick or iron. Fundamental to all of this were the invention and improvement of the elevator, electricity for implements and for lighting, thermo-glass panes for windows of all sizes and shapes, advances in the uses of computer technology to solve problems from calculating the forces of wind vortices on tall buildings to designing the undulating sheets of a Frank Gehry concert hall, and advanced telecommunications to allow the spatial separation of workers 
on the same project, whether vertically on different floors in the same building or horizontally across town or in between towns. Finally, subways and other mass transit had to be developed to get people to and from the building in an efficient manner. James Trefil has given us a comprehensive discussion of these challenges in his A Scientist in the City (Trefil, 1994).

Technological advance has enabled architects to realize the buildings they have imagined. Frank Lloyd Wright's Mile High Illinois Building would have had 528 floors and lower structures hundreds of feet below the surface. It was immediately thought to be a fantasy building with no chance of being constructed. But the Kingdom Tower will be two-thirds that height, and this would have been thought impossible a few years ago. Changes in the design of tall structures have enabled planners to conceive of vertical cities in which certain efficiencies and economies can be achieved by an extreme exaggeration of the Corbusian notion of tall buildings nested in green spaces. It has become legitimate to ask: What are the technological limitations to the height of buildings? The development of carbon-fiber rope has meant that elevators in tall buildings can travel to greater height, obviating the need to change from one elevator to another after a few dozen floors. The original motive for tall buildings, as in 19thcentury Chicago, was the cost of land and the availability of prime land. Vertical cities with clusters of 200-story buildings linked by skyways seek to capture a different set of efficiencies and economies. And many of these tall structures are being built in cities in which the climate does not invite a leisurely stroll through the street or a park. Trefil imagines one moving into the Hancock Tower in Chicago upon graduation from university and not having to leave the building, with its shops, gyms, theaters and so on, until he or she retires (Trefil, 1994, pp. 168-169). Not that this would be an inviting prospect for all of us!

\section{THE STRUCTURE OF THE BOOK}

In this book the central issue is that of how city leaders can use, and have used, architecture and architectural projects to enhance that city's economic viability and competitiveness. We will examine nine specific ways city leaders have resorted to architecture to achieve these objectives. Some of these ways focus clearly on the economic vitality of the productive enterprises in the urban region, while others have attempted to enhance the reputation, identity or status of the city. During the past century and a half, cities have become more conscious of their position relative to other cities and in many cases, such as that between New York City and Philadelphia, Liverpool and London, Toronto and Montreal, Chicago 
and St. Louis, and Turin and Milan, this competition has resulted in there being one primary city and a second less significant city. Architecture and the built environment have been used to enhance the position of many of these successful cities and also to attempt to resuscitate the city that lost the competition.

Concomitantly, what are the consequences if they fail to use architecture effectively? The risk is that they will become marginalized, with reduced economic vitality and competitiveness. We will discuss this in Chapter 10.

\section{Revival of the City}

History is replete with examples of cities, or urban economies, that have lost the heart of the local economy. This may be the result of the collapse of a single major employer, such as happened to Detroit with automobiles, or even the collapse of an entire economic sector, as with steel in many industrialized cities in the 1980s. Some cities never really recover or do so only after decades of stagnation, for some recovery comes after a path dependent rejuvenation of historic strengths, and for others a complete restructuring and refocusing are required.

In Chapter 2 we will focus on a set of cities that experienced a severe economic downturn or collapse and that then adopted the strategy of recovery through investment in architectural projects, or a single project, that redefined the essence of the city, gave inspiration to its residents and local firms, and gave the city a reputation that extended internationally. There are many examples of this, beginning with Chicago after the Great Fire in 1871 through Bilbao and the Frank Gehry Guggenheim Museum in 1997.

\section{Establishing Business Status}

Being recognized as a major center of business activity - headquarters, access to financial and other professional services, recognition of this status throughout the world, and attractiveness to other firms in their locational decisions - has motivated local leaders to accept and to encourage companies to construct major corporate headquarters buildings and sites in many of the world's major cities. Some of these efforts merely reinforced the power of the city center, while in other instances they led to renewal of a derelict part of the city, or to creation of a business center in a city that had been bereft of one. In other cities an entirely new site was developed to assert that city as a new, major economic and financial center. One of the first cities to do this was New York, from the Woolworth Building through to the Freedom Tower, and more recently we have Canary Wharf in London and La Défense in Paris. 


\section{City Status - World's Tallest Building}

Building the world's tallest (for a few years) building has been a popular way for cities to gain international status. For Chicago the Sears Tower was a natural outgrowth of the city's place in the structural development of the skyscraper since the 1880s and of the memory of Frank Lloyd Wright's notion of the "Mile High Building." For others, having the world's tallest building said to the world "Look at us!" The one kilometer tall Kingdom Tower, currently under construction in Jeddah, Saudi Arabia, is an example of this. Or it established the city as a significant location in the world of corporate centers. This latter approach has been taken by several cities in Asia or the Middle East that previously lacked status or recognition throughout the world economy and its major actors and had to adopt the strategy of "catch-up."

\section{Transformative Parks}

The Austrian Camillo Sitte celebrated Italian cities because of the fact that squares got in the way of straight streets leading the pedestrian endlessly and boringly through the city. In the US, while early Northern cities had streets that were determined more by topography and the contour of a port than anything else, by the time we get to Midtown Manhattan and post-fire Chicago the Savannah grid had become the standard.

From the mid-19th century on, there was also a desire to give access to green spaces to lower income, working class residents of the city and to immigrants. Frederick Olmsted and other landscape planners stressed the need for trees to "disinfect" the city air and for parks to improve the health of city residents. Louis Wirth, among others, argued that life in the densely populated urban setting would generate a sense of alienation; parks were seen by many as a way to ameliorate this malaise. In all cities parks were created as places for recreation and pleasure accessible to all the city's residents. In addition, large cities had dozens of smaller parks. The well-known urban parks in Europe are largely the result of initiatives far earlier than the period considered in this book - from the 1870 s on - as is the Boston Commons.

\section{Establishing a "Brand" or "Identity"}

It has become a staple of urban economics that a successful city must have something that differentiates it from other cities that are in similar situations. Branding and identity have been promoted by strategic planning consultants as being absolutely necessary for a city if it is to compete 
successfully in the struggle to gain tourist expenditures or a distinctive position in a larger geographic space, or to create an integrated economic region where there previously was none. Two examples will make this clear. Las Vegas developed its slightly off-color reputation first as a way to make itself attractive as a place to spend a few days devoted to gambling and entertainment. Later, as other gambling opportunities developed at new casinos and on native American reservations, the image had to be refined a bit to make the city attractive as a place to take the family for a different set of entertainment options. The Öresund and the Channel Tunnel initiatives have created something significant where there was not an integrated cross-border region before. Other structures, such as the St. Louis Arch or the Eiffel Tower, have given a substantive identity to a city.

\section{Relating the City to the Nation}

Architectural structures have long been used to assert political authority and identity. The wall separating East and West Berlin is a classic example. The same can be said of the wall erected by Israel through Jerusalem, and the partial wall along stretches of the US-Mexico border. Massive imposing buildings have been used in Washington, London and Moscow to consolidate and represent national political power to the citizenry and to the world. To some observers, these massive structures are intended to intimidate the citizenry and to make them feel powerless before these structures that tower over them. For others they make concrete to all the power of the collected citizenry.

Structures can also be used to represent some event that was crucial in the history of the nation, that communicates unequivocally to the citizenry, and that serves as both a symbol and a physical representation of the identity of the nation. Some may represent a domestic strife or a national triumph, while others capture the sense of a national loss of life. In all of these instances, a physical structure captures the essence of something that is powerfully felt by the citizens of the nation and draws them together in a process of creating national unity. One thinks of the Lincoln Memorial, the Arc de Triomphe and the Cenotaph. These structures also create a political unity that facilitates development of other projects and strategies that enhance the vitality of the economy. All of the structures selected here are located in cities and enhance the meaning of the city to the citizens of the nation. 


\section{Attracting a Specific Social or Economic Cohort}

There are several population cohorts that have positive consequences for the vitality and competitiveness of an urban region. Seniors, for example, can have positive impacts on a city's economy - many of them don't save, they spend, and they spend their time and money on cultural and educational activities. While some places have been created for them to spend their declining years, usually in warm climates near golf courses, others have invited them to move into dynamic and vibrant urban economies.

Wealthy financial and corporate individuals bring their wealth and spending power and help to create city environments that are attractive to tourists and shoppers. Typically the cities that seek them create living environments that are congenial to them.

Other cities have targeted younger workers, many with families, who are seeking an attractive place to work and to raise their children. They tend to be high tech workers with specific needs for culture, recreation and other amenities. Cities that create urban environments that such people find congenial are successful; those that do not may stagnate. Rapid transit, parks, green buildings, cycle paths, pedestrian ways, entertainment districts, cultural districts with museums, performance centers and theaters, and playing fields are among the architectural features that are attractive to this younger workforce. The array of city architectures that could be included in this section is quite large, and we have selected a set of examples.

\section{Creating Community}

A factor that can deter new firms and workers coming to function in a city is a sense that the city is a segregated city that is in conflict with itself. The classic example is Detroit, where the middle class, whites and firms abandoned the city for the suburbs beginning in the 1970s. Left behind were racial minorities and abandoned buildings. The city suffered a prolonged collapse from which it is only slowly recovering today. Other examples are cities in which minorities and poor residents have been "warehoused" in quarters that isolated them and left them prey to drugs, prostitution, broken homes and despair. Chicago, St. Louis, New York and Paris are prime examples of this. The belated response has been to destroy these housing units and to replace them with more "livable" residential options. In other situations, cities have created facilities that bring the various elements in the community into recreational, cultural and entertainment venues that create congenial and inviting urban living and working spaces. 


\section{When Cities Fail}

We will examine many cases of cities that have accomplished their objectives in the use of architecture in the interest of doing something to enhance the city's competitiveness. However, not all cities have been successful in what they sought to do, while other cities have simply ignored the potential benefit from resorting to architecture as a component in a strategic plan. These instances of failure will be discussed in Chapter 10, the penultimate chapter. We will look at four cities that were not successful in using architecture in the effort to revive their local economy and examples of cities that failed to have positive economic consequences from hosting major sporting events. 